\title{
Pengaruh Strategi Peningkatan Volume Usaha Terhadap Rentabilitas Pada Koperasi Karyawan Timah Mitra Mandiri Pangkalpinang
}

\author{
Nelly Astuti \\ STIE-IBEK Pangkalpinang Bangka Belitung,nellyastuti39@gmail.com
}

\begin{abstract}
ABSTRAK
Tujuan dari penelitian ini adalah untuk mengetahui pengaruh peningkatan volume bisnis terhadap rentabilitas ekonomi. Untuk menganalisis data yang diperoleh, penulis melakukan beberapa tes menggunakan NCSS 12. Dengan mengambil pengembangan volume bisnis di 7 (tujuh) unit bisnis KKMM sebagai variabel $X$ dan pengembangan rentabilitas ekonomi sebagai variabel $Y$. Dari hasil penelitian dari tahun 2013 hingga tahun 2017 yang diperoleh dari persamaan regresi adalah $\mathrm{RE}=$ $3,39740642+0,329812$ US $+3,445741$ UTbt $+0,235741$ USp $+0,407383$ UPk $+1,213757$ UT + $0,425246 \mathrm{UH}+1,515523 \mathrm{UPu}$ di mana RE $=$ Rentabilitas Ekonomi, $\mathrm{AS}=$ Unit Pemasok, UTbt = Unit tambang dan bijih timah, USp = Unit simpan dan pinjam, UPk = Unit Saluran kredit, UT = Unit Shop, $\mathrm{UH}=$ Unit Hospitality, UPu = Unit Layanan dari publik, dikenal dengan nilai R-Squared sebesar 0,988213 artinya variabel bebas mempengaruhi rentabilitas ekonomi sebesar $98,82 \%$ dan sisanya dipengaruhi oleh faktor lain yang berasal dari luar model. Dari hasil analisis, itu juga menunjukkan bahwa nilai F-Ratio sebesar 6,6246 dengan nilai probabilitas tingkat sebesar 0,00000 yang berarti bahwa keseluruhan variabel bebas pada kenyataannya dapat mempengaruhi variabel terikat secara signifikan pada tingkat $5 \%$. Dari hasil tersebut, dapat disimpulkan bahwa hipotesis yang diajukan diterima.
\end{abstract}

Kata kunci: Volume bisnis, rentabilitas ekonomi.

\begin{abstract}
The purpose of this study is to determine the effect of increasing business volume on economic profitability. To analyze the data obtained, the authors conducted several tests using NCSS 12. By taking the development of business volumes in 7 (seven) KKMM business units as variable $X$ and developing economic profitability as variables Y. From the results of research from 2013 to 2017 obtained from The regression equation is $R E=3,39740642+0,329812 U S+3,445741$ UTbt + $0,235741 U S p+0,407383 U P k+1,213757 U T+0.425246 U H+1,515523 U P u$ where $R E=$ Economic Rentability, US = Supplier Unit, UTbt = Mining and tin ore units, USp = savings and loan units, UPk = credit channel unit, $U T=$ Unit Shop, $U H=$ Hospitality Unit, $U P u=$ Service Unit from the public, known as the R-Squared value of 0.988213 meaning that the independent variable influences economic profitability of $98.82 \%$ and the rest is influenced by other factors originating from outside the model. From the analysis results, it also shows that the F-Ratio value of 6.6246 with a probability level value of 0.00000 which means that the overall independent variable can in fact influence the dependent variable significantly at the $5 \%$ level. From these results, it can be concluded that the proposed hypothesis is accepted.
\end{abstract}

Keywords: Business volume, economic profitability.

\section{A. PENDAHULUAN}

Perekonomian Indonesia ditandai oleh terjadinya dualisme ekonomi. Dualisme tidak hanya terjadi antara perekonomian desa dan kota, atau antara sektor pertanian dan industri, tetapi terjadi pula antara sektor formal dan informal di kota. Yang memprihatinkan mayoritas penduduk asli Indonesia justru berada pada sisi tidak menguntungkan dalam struktur dualistik tersebut.Hal itu tentu bertentangan dengan cita-cita Indonesia merdeka. Untuk 
menanggulangi hal tersebut, maka koperasi mendapat mandat sebagai penggalang dan pembangun kekuatan ekonomi rakyat.

Undang-Undang Dasar 1945 Khususnya pasal 33 ayat 1 , menyatakan bahwa perekonomian Indonesia disusun sebagai usaha bersama berdasar atas azaz kekeluargaan.Di mana pasal tersebut menjelaskan bahwa kemakmuran masyarakatlah yang diutamakan bukan kemakmuran perseorangan.Dan bangun perusahaan yang sesuai dengan itu adalah koperasi.Penjelasan pasal ini menempatkan koperasi baik dalam kedudukan sebagai soko guru perekonomian nasional maupun sebagai bagian integral tata perekonomian nasional.

Dengan memperhatikan kedudukankoperasi tersebut, maka peran koperasi sangatlah penting dalam menumbuhkan dan mengembangkan potensi ekonomi rakyat serta dalam mewujudkan kehidupan demokrasi ekonomi yang mempunyai ciri-ciri demokratis, kebersamaan, kekeluargaan dan keterbukaan. Dalam kehidupan ekonomi seperti itu koperasi seharusnya memiliki ruang gerak dan kesempatan usaha yang luas yang menyangkut kepentingan kehidupan ekonomi rakyat.

Usaha koperasi terutama diarahkan pada bidang usaha yang berkaitan langsung dengan kepentingan anggota baik untuk menunjang usaha maupun kesejahteraannya.Dalam hubungan ini maka pengelolaan koperasi harus dilakukan secara produktif, efektif dan efisien.Dalam arti koperasi harus mempunyai kemampuan mewujudkan pelayanan usaha yang dapat meningkatkan nilai tambah dan manfaat yang sebesar-besarnya pada anggota yang dengan tetap mempertimbangkan untuk memperoleh SHU yang wajar.

Dari kenaikan SHU tersebut maka menyebabkan tingkat rentabilitas koperasi mengalami kenaikan pula, dimana rentabilitas perusahaan menunjukkan perbandingan antara laba dengan aktiva/modal yang menghasilkan laba tersebut. Dengan kata lain, rentabilitas adalah kemampuan suatu perusahaan untuk menghasilkan laba selama periode tertentu.

Kenaikan rentabilitas di Koperasi Karyawan Timah Mitra Mandiri ini juga karena adanya efisiensi penggunaan modal kerja yang digunakan dalam meningkatkan volume usaha sehingga pendapatan yang menghasilkan laba dapat meningkat pula.

Oleh karenanya, adapun tujuan penelitian ini yaitu : Untuk mengetahui pengaruh signifikan antara strategi peningkatan volume usaha terhadap rentabilitas di Koperasi Karyawan Timah Mitra Mandiri.

\section{B. KAJIAN TEORI \\ 1) Strategi Perusahaan}

Menurut Michael A.Hitt (2010:151) pengertian strategi adalah : "Strategi adalah serangkaian komitmen dan tindakan yang terintegrasi dan terkoordinasi, yang dirancang untuk mengeksploitasi kompetisi inti dan mendapatkan keunggulan kompetitif".

Menurut William F.Glueck yang dikutip oleh R.A.Supriyono (1990:46) menyatakan bahwa :

"Strategi perusahaan adalah daerah wewenang para penyusun strategi atau disebut ahli strategi, yang dapat dikelompokkan sebagai berikut :

$>$ Para Manajer Puncak sebagai ahli strategi utama

$>$ Dewan Komisaris sebagai 
- Staf Perencana Corporate sebagai asisten manajer puncak dalam menyusun rencana dan mengimplementasikan strategi.

> Konsultan Manajemen dari luar perusahaan jika perusahaan tidak mempunyai Staf Perencana Corporate.

\section{2) Volume Usaha}

Tujuan perusahaan yang paling universal adalah mencari laba.Besar kecilnya laba tergantung daripada besar kecilnya jumlah pendapatan yang diperoleh. Berbicara mengenai jumlah pendapatan, tidak dapat dipisahkan dengan apa yang disebut volume usaha. Menurut Siswanto Sutojo (1983:54) memberikan pengertian, "Volume usaha adalah jumlah pendapatan baik yang berasal dari penjualan maupun pendapatan yang lainnya".

\section{3) Rentabilitas}

Umumnya suatu laporan keuangan (financial statement) atau financial report terdiri dari balance sheet (neraca) dan loss statement (perhitungan laba-rugi), laporan perubahan posisi keuangan dan catatan atas laporan keuangan. Menganalisis suatu financial statement secara berurutan, dapat diketahui kondisi keuangan suatu perusahaan selama satu periode tertentu, terutama yang berkaitan dengan rentabilitas, likuiditas, dan solvabilitas.

Sehubungan dengan variabel yang terkait adalah rentabilitas, maka dalam penelitian ini yang lebih dibahas adalah rasio rentabilitas.Suatu usaha yang menghasilkan laba tidak selamanya dikatakan sebagai usaha yang menguntungkan (rendable) atau sebagai usaha yang efisien.Ukuran yang dipergunakan untuk menilai kegiatan usaha yang rendable dan efisien adalah rentabilitas. Rentabilitas usaha hanya dapat terjadi apabila penggunaan sumber-sumber dana dapat memberikan hasil lebih terhadap nilai input yang dipergunakan.

Menurut Bambang Riyanto (2010:28), pengertian rentabilitas adalah:

"Rentabilitas adalah kemampuan suatu perusahaan untuk menghasilkan laba selama periode tertentu, dan umumnya dirumuskan sebagai $\frac{\mathrm{L}}{\mathrm{M}} \times 100 \%$ dimana $L$ adalah jumlah laba yang diperoleh selama periode tertentu dan $M$ adalah modal atau aktiva yang digunakan untuk menghasilkan laba tersebut".

Besar kecilnya tingkat rentabilitas ekonomis suatu perusahaan dipengaruhi oleh beberapa faktor, yaitu:

a) Profit Margin

Profit margin merupakan perbandingan antara laba usaha sebelum pajak/bunga dengan jumlah hasil penjualan yang dinyatakan dengan persentase.Profit margin dimaksudkan untuk mengetahui efisiensi perusahaan dengan melihat kepada besar kecilnya laba usaha dalam hubungannya dengan penjualan. Menurut S. Munawir (2000:105) dirumuskan sebagai berikut:

$$
\text { Profit Margin : } \frac{\text { EBIT }}{\text { Sales }} \quad \text { X 100\% }
$$

* EBIT = Earning Before Interest and Tax

Ada dua alternatif dalam usaha untuk memperbesar profit margin, yaitu :

Dengan menambah biaya usaha sampai tingkat tertentu dimana tercapainya tambahan penjualan yang sebesar besarnya, dengan catatan bahwa tambahan 
penjualan harus lebih besar daripada tambahan biaya usaha. Misalnya dengan memperbesar volume penjualan sampai tingkat tertentu atau menaikkan harga jual per unit pada luas penjualan unit tertentu.

Mengurangi pendapatan dari penjualan sampai tingkat tertentu dimana terjadi pengurangan biaya usaha yang lebih besar dibanding dengan jumlah pengurangan dari penjualan.

b) Turnover of Operating Assets

Turnover of operating assets atau tingkat perputaran aktiva adalah kecepatan berputarnya aktiva usaha dalam suatu periode tertentu. Perputaran tersebut dapat ditentukan dengan membagi penjualan bersih dengan aktiva usaha, menurut $S$. Munawir (2000:105) dirumuskan sebagai berikut :

$$
\text { Tingkat Perputaran Aktiva }=\frac{\text { Penjualan }}{\text { Aktiva Usaha }}
$$

Tingkat perputaran aktiva dimaksudkan untuk membatasi efisiensi usaha dengan melihat kecepatan perputaran aktiva usaha dalam periode tertentu. Sama halnya dengan profit margin, tingkat perputaran aktiva juga dapat dipertinggi dengan cara :

> Dengan menambah modal usaha sampai tingkat tertentu diusahakan tercapainya tambahan penjualan sebesarbesarnya.

Dengan mengurangi penjualan
sampai tingkat tertentu
diusahakan penurunan atau
pengurangan modal usaha
sebesar-besarnya.

Dari penjelasan di atas, dilihat bahwa volume modal kerja mempunyai keterkaitan dengan rentabilitas ekonomis yaitu perkalian antara profit margin dengan perputaran modal usaha. Menurut S. Munawir (2000:105) dapat dirumuskan sebagai berikut :

Rentabilitas Ekonomi = Profit Margin $\mathrm{x}$ Tingkat Perputaran Aktiva

Sedangkan hubungan antara profit margin dengan dengan perputaran aktiva, menurut S.Munawir (2000:105) dapat dirumuskan sebagai berikut :

$$
\frac{\text { Net Opearting Income }}{\text { Net Operating Asset }}=\frac{\text { Net Opearting Income }}{\text { Net Sales }} \quad x \quad \frac{\text { Net Sales }}{\text { Net Operating Asset }}
$$

\section{METODE PENELITIAN}

Penelitian ini menggunakan pendekatan deskriftif kuantitatif. Data yang digunakan dalam penelitian ini adalah Data Skunder (Secondary Data) dengan teknik pengumpulan data melalui wawancara, observasi dan studi kepustakaan. Untuk menganalisa data-data yang diperoleh dalam rangka memecahkan pokok permasalahan dalam penelitian ini, penulis melakukan pengujian dengan 
NCSS 12 dengan analisis regresiuntuk menganalisis data yang diperoleh dalam rangka memecahkan pokok permasalahan dalam penelitian iniyaitu untuk mengetahui sejauh mana pengaruh strategi peningkatan volume usaha terhadap rentabilitas ekonomis Koperasi Karyawan Timah Mitra Mandiri.

\section{HASIL PENELITIAN}

Koperasi sebagai badan usaha yang mempunyai berbagai kegiatan usaha harus dapat mengelola aktivitas usaha tersebut sehingga memberikan keuntungan baik bagi koperasi maupun bagi anggotanya. Tolak ukur perkembangan kegiatan atau aktivitas usaha koperasi dari besarnya volume usaha yang diperoleh diharapkan koperasi dapat meningkatkan pelayanan pada para anggotanya. Jadi volume usaha juga merupakan salah satu prestasi koperasi dalam menjalankan aktivitasnya.

$$
\text { Untuk mengetahui }
$$

perkembangan volume usaha Koperasi Karyawan Timah Mitra Mandiri dapat dilihat pada tabel berikut:

\begin{tabular}{|c|l|r|r|r|r|r|}
\hline No & \multicolumn{1}{|c|}{ Unit Usaha } & \multicolumn{1}{c|}{$\mathbf{2 0 1 3}$} & \multicolumn{1}{c|}{$\mathbf{2 0 1 4}$} & \multicolumn{1}{c|}{$\mathbf{2 0 1 5}$} & \multicolumn{1}{c|}{$\mathbf{2 0 1 6}$} & \multicolumn{1}{c|}{$\mathbf{2 0 1 7}$} \\
\hline 1 & Unit Supplier & $3,209,973,014$ & $1,722,809,629$ & $1,987,011,562$ & $2,265,963,519$ & $3,328,112,677$ \\
2 & Unit Tambang dan Biji & & & & & \\
& Timah & $1,331,400,000$ & $2,573,143,222$ & $37,100,559,032$ & $73,142,570,236$ & $71,928,930,405$ \\
3 & Unit Simpan Pinjam & $246,565,040$ & $280,083,834$ & $393,747,567$ & $707,616,336$ & $732,252,177$ \\
4 & Unit Penyaluran Kredit & $395,741,992$ & $403,698,804$ & $454,850,496$ & $548,475,170$ & $483,334,750$ \\
5 & Unit Toko & $2,890,632,808$ & $2,380,173,226$ & $2,421,261,457$ & $2,273,632,211$ & $2,336,761,274$ \\
6 & Unit Hospitality & $151,625,808$ & $216,096,499$ & $324,993,192$ & $417,400,827$ & $501,714,618$ \\
7 & Unit Pelayanan Umum & $5,251,400$ & $123,048,146$ & $58,275,753$ & $100,291,347$ & $131,244,775$ \\
\hline \multicolumn{2}{|c|}{ Total } & $\mathbf{8 , 2 3 1 , 1 9 0 , 0 6 2}$ & $\mathbf{7 , 6 9 9 , 0 5 3 , 3 6 0}$ & $\mathbf{4 2 , 7 4 0 , 6 9 9 , 0 5 9}$ & $\mathbf{7 9 , 4 5 5 , 9 4 9 , 6 4 6}$ & $\mathbf{7 9 , 4 4 2 , 3 5 0 , 6 7 6}$ \\
\hline
\end{tabular}

\begin{abstract}
Berdasarkan tabel di atas dapat pula diketahui persentase perkembangan dari masing-masing unit usaha tersebut dengan cara melihat perbandingan dari kenaikan volume usaha tersebut dari tahun berikutnya dengan tahun sebelumnya.
\end{abstract}

\section{Unit Usaha Supplier}

Volume usaha dari unit usaha supplier pada tahun 2014 atas tahun 2013 turun sebesar $46 \%$ hal ini terjadi karena menurunnya jumlah permintaan dari PT. Timah ataupun karena telah habis kontraknya. Pada tahun 2014 ke tahun 2015 terjadi peningkatan volume usaha sebesar $15 \%$, begitu pula pada tahun 2016, terjadi peningkatan $14 \%$ dari tahun sebelumnya yaitu tahun 2015 , hal ini terjadi karena koperasi mencari peluang pengadaan barang/jasa di PT. Timah guna membantu program PT. Timah yaitu cutting cost melalui penetapan margin rendah dan kualitas sesuai spektek. Untuk volume usaha pada tahun 2017 atas tahun 2016 terjadi peningkatan yang cukup besar yaitu sebesar 47\%. Hal ini terjadi karena Koperasi Karyawan Timah Mitra Mandiri menang tender dan order selanjutnya ke KKMM.

\section{Unit Usaha Tambang dan Bijih Timah}

Volume usaha dari unit usaha tambang dan bijih timah pada tahun 2014 atas tahun 2013 naik sebesar 93\% dan tahun 2015 atas tahun 2014 juga mengalami kenaikan sebesar 
$1342 \%$, begitu pula tahun 2016 atas tahun 2015 mengalami peningkatan pada volume usahanya yaitu sebesar $97 \%$. Hal ini terjadi karena pada tahun 2014 usaha bijih timah baru berjalan efektif per 1 Oktober 2014 dan margin yang ditetapkan Rp.300/kg sn. Selain itu harga beli bijih timah pada tahun 2015 oleh PT. Timah mengalami kenaikan dibandingkan tahun 2014.Dalam hal ini KKMM mendapat kepercayaan dari mitra tambang berkaitan dengan kecepatan dalam hal pembayaran dan pelayanan. Volume usaha pada tahun 2017 atas tahun 2016 mengalami penurunan sebesar $2 \%$, hal ini terjadi karena disebabkan usaha bijih timah masih tergantung pada ketetapan harga bijih timah dari PT. Timah sehingga penentuan margin lebih rendah agar bisa bersaing dengan pembeli di luar, dimana harga beli smelter swasta dan Kobatin selalu lebih tinggi.

\section{Unit Usaha Simpan Pinjam}

Volume usaha unit simpan pinjam tahun 2014 atas tahun 2013 naik sebesar $14 \%$, hal ini terjadi karena adanya pinjaman barang yang keuntungan dari harga jual barang dan bunga pinjaman. Volume usaha tahun 2015 atas tahun 2014 juga mengalami kenaikan sebesar $41 \%$, begitu pula pada tahun 2016 atas tahun 2015 mengalami kenaikan lagi sebesar $80 \%$, hal ini cukup proporsional mengingat terjadinya kenaikan pinjaman dari anggota sangat tinggi dengan adanya kenaikan plafon, pinjaman berupa barang dan bunga pinjaman tetap sebesar $12 \%$ per tahun. Volume usaha pada tahun 2017 atas tahun 2016 sedikit mengalami kenaikan yaitu sebesar $3 \%$, hal ini terjadi karena penurunan minat anggota untuk meminjam berupa barang.

\section{Unit Usaha Penyaluran Kredit}

Volume usaha unit penyaluran kredit tahun 2014 atas tahun 2013 naik sebesar $2 \%$, dikarenakan program PPRM dan PPKM sudah ditiadakan oleh PT. Timah dan program yang masih berjalan adalah PPAM. Pada tahun 2015 atas tahun 2014 juga mengalami kenaikan sebesar 13\% dikarenakan adanya tambahan fasilitas beserta jasa pengelolaannya dari Rp.6,7 juta menjadi Rp.8,5 juta per bulan. Volume usaha juga naik pada tahun 2016 atas tahun 2015 sebesar $21 \%$, namun pada tahun 2017atas tahun 2016 mengalami penurunan sebesar $12 \%$, hal ini karena hanya mengandalkan fee jasa pengelolaan PPAM, PPKM, dan PPRM yang sifatnya tetap.

\section{Unit Usaha Toko}

Volume usaha unit toko tahun 2014 atas tahun 2013 turun sebesar $18 \%$, hal ini terjadi karena tingkat persaingan sangat ketat dan hasil ini menunjukkan usaha murni toko tanpa natura. Upaya yang dilakukan adalah dengan melakukan pembelian barang dagangan dari distributor di luar Bangka dan menambah kegiatan usaha grosir untuk menutupi beban PPn, hasilnya dapat terlihat pada tahun 2015, dimana volume usaha mengalami kenaikan sebesar $2 \%$ atas tahun sebelumnya yaitu tahun 2014 . Pada tahun 2016 atas tahun 2015 volume usaha mengalami penurunan kembali sebesar $6 \%$, hal ini terjadi karena usaha toko secara filosofis untuk memenuhi kebutuhan anggotanya dan memberikan kemudahan dalam pembayaran secara kredit dengan harga jual rendah sehingga PPn atas belanja anggota ditanggung KKMM, di samping itu beban toko Sungailiat sangat tinggi berupa penyusutan gedung dan inventaris. Volume usaha pada tahun 
2017 atas tahun 2016 naik sebesar 3\%. Untuk mengatasi permasalahan yang terjadi pada tahun-tahun sebelumnya KKMM melakukan beberapa upaya, diantaranya melakukan analisa stock dan penentuan plafon yang objektif.

\section{Unit Usaha Hospitality}

Volume usaha hospitality pada tahun 2014 atas tahun 2013 naik sebesar 43\%, begitu pula tahun 2015 atas tahun 2014 juga naik sebesar $50 \%$. Kondisi ini disebabkan pemulihan omset penjualan dan pengembangan distribusi air dan pemotongan rumput di sekitar perumahan Bukit Baru. Pada tahun 2016 atas tahun 2015 volume usaha naik sebesar $28 \%$,juga terus terjadi kenaikan pada tahun 2017 atas tahun 2016 sebesar 20\%. Hal ini karena meningkatnya volume pengunjung renang dan fitness/Aerobic di BBSC serta kontribusi jasa distribusi air dan pemotongan rumput di sekitar perumahan Bukit Baru.

\section{Unit Usaha Pelayanan Umum}

Volume usaha unit pelayanan umum pada tahun 2014 atas tahun 2013 naik sebesar 2243\% , namun kinerja unit usaha ini belum dapat diperbandingkan kinerjanya, karena merupakan gabungan usaha warnet, gedung serba guna, angkutan bijih timah dan garmen, tetapi dalam RKAU dan tahun 2013 hanya meliputi warnet dan garmen. Volume usaha unit pelayanan umum pada tahun 2015 atas tahun 2014 mengalami penurunan sebesar $53 \%$ disebabkan adanya kontribusi jasa angkutan bijih timah pada tahun 2014, selain itu juga kondisi usaha gedung serbaguna masih pada tahap promosi, dan warnet adalah usaha yang bersifat musiman (ramai pada saat libur sekolah). Namun pada tahun 2016 volume usaha mengalami kenaikan atas tahun 2015 sebesar 72\%. Begitu pula pada tahun 2017 atas tahun 2016 juga naik sebesar $31 \%$, hal ini disebabkan karena operasional fotocopy dan gedung serbaguna telah menunjukkan perkembangan yang baik, walaupun terus rugi tapi menunjukkan kerugian yang terus menurun.

\section{E. PEMBAHASAN}

1) Pengujian Pengaruh Strategi Peningkatan Volume Usaha terhadap Rentabilitas Ekonomis pada Koperasi Karyawan Timah Mitra Mandiri Untuk melihat bagaimana pengaruh strategi peningkatan volume usaha terhadap kenaikan rentabilitas ekonomis, maka perlu untuk melakukan analisis secara simultan. Input yang digunakan adalah data perkembangan volume usaha dari masing-masing unit usaha terhadap perkembangan rentabilitas ekonomis antara tahun 2013 sampai dengan tahun 2017.

Tabel Hasil Uji Statistik Pengaruh Kenaikan Volume Usaha dariUnit Usaha secara Keseluruhan terhadap Rentabilitas Ekonomis.

\begin{tabular}{|l|r|r|c|}
\hline \multicolumn{1}{|c|}{ Variabel } & \multicolumn{1}{c|}{$\begin{array}{c}\text { Koefisien } \\
\text { regresi }\end{array}$} & $\begin{array}{c}\text { Tingkat } \\
\text { kemungkinan }\end{array}$ & Keputusan 5 \% \\
\hline Intercept & 3,39740642 & 0,005534 & Reject Ho \\
\hline Unit supplier & 0,329812 & 0,003890 & Reject Ho \\
\hline Unit tambang & 3,445741 & 0,002348 & Reject Ho \\
\hline Unit simpan pinjam & 0,235741 & 0,002768 & Reject Ho \\
\hline
\end{tabular}




\begin{tabular}{|l|r|r|r|}
\hline Unit penyaluran kredit & 0,407383 & 0,002871 & Reject Ho \\
\hline Unit toko & 1,213757 & 0,003164 & Reject Ho \\
\hline Unit hospitality & 0,425246 & 0,004261 & Reject Ho \\
\hline Unit pelayanan umum & 1,515523 & 0,004426 & Reject Ho \\
\hline R-Squared $=0,988213$ & F ratio $=6,6246$ & Prob Level $=0,00000$ \\
\hline Multicollinearity is NOT a problem \\
\hline
\end{tabular}

Seperti terlihat pada tabel di atas, nilai R-Squared menunjukkan nilai sebesar 0,988213 atau $98,82 \%$ berarti bahwa variabel bebas mempengaruhi rentabilitas ekonomis sebesar $98,82 \%$ dan sisanya dipengaruhi oleh faktor lain yang berasal dari luar model. Analisis selanjutnya adalah analisis ragam yang menunjukkan apakah secara bersama-sama variabel bebas mampu menerangkan variabel terikat secara signifikan. Hasil analisis menunjukkan bahwa nilai F-ratio sebesar 6,6246 dengan nilai probabilitas level sebesar 0,00000 yang berarti bahwa keseluruhan variabel bebas ternyata mampu mempengaruhi variabel terikat secara signifikan pada tingkat signifikansi $5 \%$.

Untuk melihat pengaruh parsial, dilakukan uji T diperoleh nilai-nilai uji T secara berturut-turut $=12,2649$; 12,$3127 ; 12,5164 ; 12,6721 ; 12,9120$ ; 12,1246 ; 12,2038 dengan probabilitas level semuanya sebesar = $0.004261 ; 0.003164 ; 0.002348$; $0.003890 ; 0.002871 ; 0.004426$; 0.002768 pada tingkat signifikansi $5 \%$ yang berarti setiap masing-masing unit usaha secara parsial mampu mempengaruhi rentabilitas ekonomis secara signifikan. Dari tabel t diketahui bahwa unit pelayanan umum yang paling besar berpengaruh secara signifikan terhadap rentabilitas ekonomis.

Berdasarkan pengolahan data, ternyata dalam model tidak terdapat permasalahan seperti multicolinieritas dan otokorelasi yang signifikan yang mampu mempengaruhi interpretasi yang dihasilkan, sehingga dapat disimpulkan bahwa model ini cukup baik untuk menghasilkan kesimpulan kesimpulan yang akurat.

Secara matematis, model statistik yang dihasilkan dapat dibuat dalam bentuk

\section{$\mathrm{RE}=3,39740642+0,329812 \mathrm{US}+3,445741 \mathrm{UTbt}+0,235741 \mathrm{USp}+0,407383 \mathrm{UPk}+$ $1,213757 \mathrm{UT}+0,425246 \mathrm{UH}+1,515523 \mathrm{UPu}$}

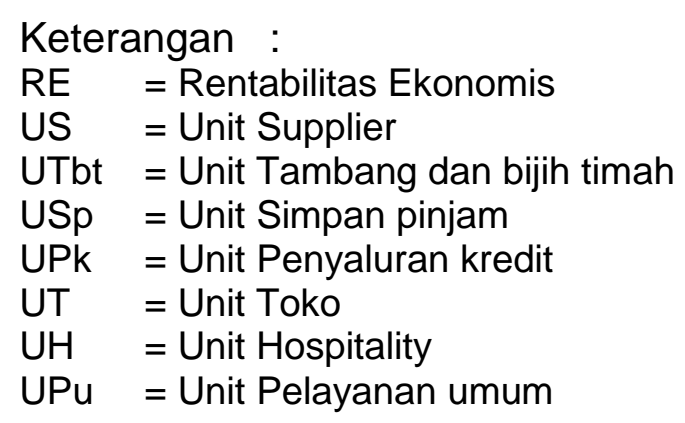

Nilai sebesar 0,329812 pada unit supplier mengandung pengertian bahwa setiap kenaikan 1 unit volume usaha pada unit usaha supplier mampu meningkatkan rentabilitas ekonomis sebesar 0,329812.Sedangkan nilai sebesar 3,445741 pada unit tambang dan bijih timah mengandung pengertian bahwa setiap kenaikan 1 unit volume usaha pada unit usaha tambang dan bijih timah mampu meningkatkan rentabilitas ekonomis sebesar 3,445741 . 
Nilai sebesar 0,235741 pada unit simpan pinjam mengandung pengertian bahwa setiap kenaikan 1 unit volume usaha pada unit usaha simpan pinjam mampu meningkatkan rentabilitas ekonomis sebesar 0,235741 .Nilai sebesar 0,407383 pada unit penyaluran kredit mengandung pengertian bahwa setiap kenaikan 1 unit volume usaha pada unit usaha penyaluran kredit mampu meningkatkan rentabilitas ekonomis sebesar 0,407383.

Nilai sebesar 1,213757 pada unit toko mengandung pengertian bahwa setiap kenaikan 1 unit volume usaha pada unit usaha toko mampu meningkatkan rentabilitas ekonomis sebesar 1,213757.Nilai sebesar 0,425246 pada unit hospitality mengandung pengertian bahwa setiap kenaikan 1 unit volume usaha pada unit usaha hospitality mampu meningkatkan rentabilitas ekonomis sebesar 0,425246.Nilai sebesar 1,515523 pada unit pelayanan umum mengandung pengertian bahwa setiap kenaikan 1 unit volume usaha pada unit usaha pelayanan umum mampu meningkatkan rentabilitas ekonomis sebesar 1,515523.

\section{F. KESIMPULAN}

Dalam penelitian ini yang dilakukan secara simultan melalui pengujian NCSS 2000 (Normally Computerized Social System), bahwa dari hasil perhitungan statistik secara simultan antara variabel $X$ (strategi peningkatan volume usaha) yang terdiri dari perkembangan volume usaha US (Unit Supplier), UTbt (Unit Tambang dan bijih timah), USp (Unit Simpan pinjam), UPk (Unit Penyaluran kredit), UT (Unit Toko), UH (Unit Hospitality) dan UPu (Unit Pelayanan umum) terhadap variabel $Y$ yaitu rentabilitas ekonomis. Maka dapat disimpulkan bahwa seluruh unit usaha pada KKMM mempunyai pengaruh positif terhadap rentabilitas ekonomis. Artinya bahwa dengan peningkatan volume usaha maka akan meningkatkan rentabilitas ekonomis pula. Dari hasil analisis penghitungan persamaan regresi linearnya yaitu :

\section{$\mathrm{RE}=3,39740642+0,329812 \mathrm{US}+3,445741 \mathrm{UTbt}+0,235741 \mathrm{USp}+0,407383 \mathrm{UPk}+1,2137$} $57 \mathrm{UT}+0,425246 \mathrm{UH}+1,515523 \mathrm{UPu}$

Dengan nilai R-Squared menunjukkan nilai sebesar 0,988213 atau $98,82 \%$ berarti bahwa variabel bebas mempengaruhi rentabilitas ekonomis sebesar 98,82\% dan sisanya dipengaruhi oleh faktor lain yang berasal dari luar model. Dan hasil pengujian statistik uji $T$ sebesar 12,2649 - 12,2038 dengan probabilitas level semuanya sebesar $=0.004261$ 0.002768 pada tingkat signifikansi $5 \%$ menunjukkan $\mathrm{H}_{0}$ penelitan ditolak dan itu berarti bahwa $\mathrm{H}_{1}$ penelitian diterima yaitu ada pengaruh yang signifikan antara strategi peningkatan volume usaha terhadap rentabilitas ekonomis karena dalam setiap unit usaha KKMM terjadi peningkatan volume usaha setiap tahun sehingga berdampak pada kenaikan rentabilitas ekonomis

\section{DAFTAR PUSTAKA}
Basu Swastha, , "Manajemen Penjualan", edisi 3, BPFE:Yogyakarta. 2010

Downes, John, Jordan Elliot Goodman, 2000, "Kamus Istilah Keuangan dan Investasi”, Kelompok Gramedia : Jakarta. 
Fandy Tjiptono, Strategi Pemasaran, Edisi 3, 2008

Hansen, Don. R. Mowen, Maryanne M, "Akuntansi Biaya", Edisi ketujuh, Salemba Empat : Jakarta, 2006

Hongren, Charles T. Geogle Foster. "Cost Accounting : A Managerial Emphasis". Eight Edition, Pretice Hall International, New Jersey, 2011

Ikatan Akuntansi Indonesia, Standar Akuntansi Keuangan. Jakarta : Salemba Empat, (2013)
Michael A.Hitt, Organizational Behaviour, $3^{\text {rd }}$ Edition.

Moekijat, "Kamus Manajemen", CV. Mandar Maju: Bandung. , 2000

Mulyadi, Akuntansi Biaya, Aditya Media, Edisi ke-5, Yogyakarta, 2010

R. A. Supriyono, S.U. 2000. Sistem Pengendalian Manajemen. Edisi Pertama. Yogyakarta: BPFE 